Wioleta Kitowskal, Matgorzata Stępieñ ${ }^{l}$, Magdalena Rosińskal, Katarzyna Szmulik', Matgorzata Jamsheer-Bratkowska ${ }^{2}$, Pawet Budziosz ${ }^{l}$, Matgorzata Sadkowska-Todys ${ }^{l}$

\title{
COVID-19 MODULE IN SRWE SYSTEM - APPLICATION AND USE IN EPIDEMIOLOGICAL SURVEILLANCE AND REPORTING TO INTERNATIONAL INSTITUTIONS
}

\author{
MODUŁ COVID-19 W SRWE - ZASTOSOWANIE I WYKORZYSTANIE \\ W NADZORZE EPIDEMIOLOGICZNYM ORAZ RAPORTOWANIU DO INSTYTUCJI \\ MIĘDZYNARODOWYCH
}

\author{
National Institute of Public Health - National Institute of Hygiene \\ ${ }^{1}$ Department of Epidemiology of Infectious Diseases and Surveillance \\ ${ }^{2}$ Department of Environmental Health and Safety \\ Narodowy Instytut Zdrowia Publicznego - Państwowy Zakład Higieny \\ ${ }^{1}$ Zakład Epidemiologii Chorób Zakaźnych i Nadzoru \\ ${ }^{2}$ Zakład Bezpieczeństwa Zdrowotnego Środowiska
}

\begin{abstract}
The new SARS-CoV-2 (Severe Acute Respiratory Syndrome Coronavirus-2) coronavirus causing acute respiratory disease COVID-19 (2019 coronavirus disease) detected in China in 2019 very quickly revealed its epidemic potential and was recognized as a global health problem.

The situation caused by the rapidly increasing number of new cases and deaths due to COVID-19 required the rapid development of international recommendations and procedures to limit the spread of infections and ongoing monitoring of the epidemiological situation.

In the field of epidemiological surveillance of COVID-19 cases, international organizations - WHO and regionally ECDC, have developed basic requirements for reporting data on newly detected cases of infection.

In order to ensure the possibility of reporting new cases and activities undertaken by sanitary-epidemiological services in the country and to fulfill the obligation to report data to the European surveillance network, it was necessary to adapt the electronic system supporting epidemiological surveillance operations, for registration of suspected and confirmed cases of SARS-CoV-2 infections.

This work presents the characteristics of the new COVID-19 module created as part of the central Epidemiological Case Reporting System and a preliminary evaluation of its usefulness for the purposes of combating COVID-19. CONCLUSIONS. The Epidemiological Case Reporting System is an efficient and adequate tool that can be adapted to newly emerging threats. In order to use the module to monitor the current epidemiological situation, it is necessary to integrate it with other systems collecting data about COVID-19 patients - ie. EWP and the clinical patient register.
\end{abstract}

Key words: COVID-19, SARS-CoV-2, coronavirus, epidemiological surveillance, epidemiology

\section{STRESZCZENIE}

Nowy koronawirus SARS-CoV-2 (Severe Acute Respiratory Syndrome Coronavirus-2) wywołujący ostrą chorobę układu oddechowego COVID-19 (coronavirus disease 2019) wykryty w Chinach w 2019 r. bardzo szybko ujawnił swój potencjał epidemiczny i został uznany za globalny problem zdrowotny.

Sytuacja wywołana gwałtownie narastającą liczbą nowych zachorowań i zgonów z powodu COVID-19 wymagała szybkiego opracowania międzynarodowych zaleceń i sposobów postępowania $\mathrm{w}$ celu ograniczenia szerzenia się zakażeń oraz bieżącego monitorowania sytuacji epidemiologicznej.

(c) National Institute of Public Health - National Institute of Hygiene / Narodowy Instytut Zdrowia Publicznego - Państwowy Zakład Higieny 
W obszarze nadzoru epidemiologicznego nad przypadkami COVID-19 organizacje międzynarodowe - WHO oraz regionalnie ECDC, opracowały podstawowe wymagania dotyczące raportowania danych o nowo wykrytych przypadkach zakażeń.

W celu zapewnienia możliwości rejestracji nowych zachorowań i działań podejmowanych przez służby sanitarno-epidemiologiczne w kraju oraz wypełnienia obowiązku raportowania danych do europejskiej sieci nadzoru niezbędne było dostosowanie elektronicznego systemu wspierającego działanie nadzoru epidemiologicznego do rejestracji podejrzeń i potwierdzonych przypadków zakażeń SARS-CoV-2.

W prezentowanej pracy przedstawiono charakterystykę nowego modułu COVID-19 utworzonego w ramach centralnego Systemu Rejestracji Wywiadów Epidemiologicznych oraz wstępną ewaluację jego użyteczności do celów zwalczania COVID-19.

WNIOSKI. System Rejestracji Wywiadów Epidemiologicznych jest sprawnym i adekwatnym narzędziem, które może być dostosowywane do nowo pojawiających się zagrożeń. W celu wykorzystania modułu do monitorowania bieżącej sytuacji epidemiologicznej niezbędna jest integracja z pozostałymi systemami gromadzącymi dane o pacjentach z COVID-19 - EWP oraz klinicznym rejestrem pacjentów.

Slowa kluczowe: COVID-19, SARS-CoV-2, koronawirus, nadzór epidemiologiczny, epidemiologia

\section{INTRODUCTION}

The first cases of pneumonia caused by an unknown etiological agent were reported by China in the city of Wuhan at the beginning of December 2019 (1). The etiological agent identified as a result of genome sequencing turned out to be a new, previously unknown virus belonging to the beta-coronavirus genus, later named SARS-CoV-2, due to its almost $80 \%$ similarity to the SARS coronavirus (also called SARS-CoV-1) (2).

The rapidly increasing number of patients in Wuhan and the first reported death from SARSCoV-2 at the beginning of January 2020 led to the implementation of radical measures to reduce the spread of infection.

Actions undertaken in China, which significantly minimized contacts between people, considerably reduced the epidemic in Wuhan and slowed its spread (3-5), but failed to stop the epidemic within one country. WHO and other international organizations quickly issued recommendations on the diagnosis, epidemiological surveillance of SARS-CoV-2 (including the publication of the case definition on January 22, 2020), and the treatment of infected individuals. On March 11, the World Health Organization declared COVID-19 a pandemic (6) (the new name for the virus and its disease was adopted on February 25, 2020), after the total number of confirmed cases exceeded 118,000 and cases were reported in 114 countries around the world.

Poland initiated preparations in the event of imported infections as early as January 2020, among others for reasons due to the evacuation of Polish citizens from the then closed city of Wuhan - a group of students staying in Wuhan for a scientific exchange returned to Poland on January 25 (7); on February 2 , another large group of Poles was evacuated from

\section{WSTĘP}

Pierwsze przypadki zachorowań na zapalenie płuc wywoływane przez nieznany wówczas czynnik etiologiczny odnotowano w Chinach w mieście Wuhan na początku grudnia 2019 r. (1)China, was caused by a novel betacoronavirus, the 2019 novel coronavirus (2019-nCoV. Czynnikiem etiologicznym, zidentyfikowanym w wyniku sekwencjonowania genomu okazał się nowy, wcześniej nieznany wirus należący do rodzaju betakoronawirusów, nazwany później SARS-CoV-2, ze względu na jego prawie $80 \%$ podobieństwo do koronawirusa SARS (zwanego też SARS-CoV-1) (2)

Błyskawicznie narastająca liczba chorych w Wuhan oraz odnotowanie na początku stycznia 2020 pierwszego zgonu z powodu SARS-CoV-2 doprowadziły do wdrożenia radykalnych środków, mających na celu ograniczenie szerzenia się zakażeń.

Podjęte w Chinach działania, które znacząco minimalizowały kontakty między ludźmi w sposób istotny wpłynęły na ograniczenie epidemii w Wuhan i spowolnienie jej rozprzestrzeniania się (3-5), jednak nie zdołały zatrzymać epidemii w granicach jednego kraju. WHO i inne organizacje międzynarodowe w krótkim czasie wydały zalecenia dotyczące diagnostyki, nadzoru epidemiologicznego nad SARS-CoV-2 (w tym opublikowano definicję przypadku 22 stycznia 2020 r.) oraz postępowania z osobami, u których wykryto zakażenie. W dniu 11 marca Światowa Organizacja Zdrowia ogłosiła pandemię COVID-19 (6) (nowa nazwa dla wirusa i choroby przez niego wywoływanej przyjęta 25 lutego 2020 r.), dopiero gdy całkowita liczba potwierdzonych przypadków przekroczyła 118 tysięcy, a zachorowania odnotowano w 114 krajach świata.

Polska podjęła pierwsze przygotowania na wypadek wystąpienia importowanych zakażeń już w styczniu 2020 r., między innymi w związku z ewakuacją obywateli Polski z wówczas już zamkniętego miasta 
Wuhan along with citizens of other countries, by air transport organized by the French authorities. All evacuees were hospitalized and infection with SARS-CoV-2 was excluded on the basis of the results of molecular tests (8). Work to prepare the country for an epidemic was carried out on many levels, but one of the most important elements was the development of operational procedures of the State Sanitary Inspection, including procedures for management of people potentially at risk of infection, utilizing measures such as quarantine and epidemiological surveillance, and the guidelines for testing for SARSCoV- 2.

The first case of COVID-19 in Poland was confirmed on March 4, 2020 in a 66-year-old man from the Lubuskie voivodeship, who came by coach from Germany on March 1, where he was probably infected (9).

At this time, 4290 cases of COVID-19 (data as of March 5, 2020) had already been diagnosed in European countries, of which over 3000 were reported in Italy and over 260 in Germany.

Within four months, until June 30, 2020, a total of 34154 cases of infection were recorded in Poland, of which 1444 were fatal, while in Europe the total number of confirmed cases exceeded 2400000 and the number of deaths was approximately 191000 (10).

The rapidly developing global crisis also required actions allowing for ongoing monitoring of the situation at the international level. Epidemiological surveillance of COVID-19 cases since the outbreak in China was first discovered has been organized and supported at the global level by WHO in collaboration with organizations operating in individual regions. Pursuant to Regulation (EC) 851/2004 of the European Parliament and of the Council, EU/EEA countries (and the United Kingdom) are required to provide information on infectious diseases through appropriate, nationally designatated institutions or directly by the authorities of the country to the European network for epidemiological surveillance and control of communicable diseases established in 1998 (by decision 2119/98/EC of the European Parliament and of the Council).

At the end of January 2020, the first protocol for reporting COVID-19 cases to the European Surveillance System (TESSy) was released by ECDC. Updated versions of the protocol were published in the following months (11).

According to the first protocol, individual case reports should be submitted to the European network within 24 hours of detection and contain key epidemiological data on probable and confirmed cases, classified according to the surveillance case definition.
Wuhan - 25 stycznia do Polski powróciła grupa studentów przebywających w Wuhan na wymianie naukowej (7); 02 lutego kolejna duża grupa Polaków została ewakuowana z Wuhan wraz z obywatelami innych krajów, transportem lotniczym zorganizowanym przez władze Francji. Wszystkie osoby ewakuowane poddano hospitalizacji oraz wykluczono zakażenie SARS-CoV-2 na podstawie wyników przeprowadzonych badań molekularnych (8). Prace przygotowujące kraj na stan epidemii były prowadzone na wielu płaszczyznach, ale jednym z ważniejszych elementów było opracowanie procedur funkcjonowania Państwowej Inspekcji Sanitarnej, $\mathrm{w}$ tym procedur postępowania $\mathrm{z}$ osobami potencjalnie narażonymi na zakażenie takich jak kwarantanna i nadzór epidemiologiczny oraz zasady testowania w kierunku SARS-CoV-2.

Pierwszy przypadek COVID-19 w Polsce potwierdzono w dn. 4 marca 2020 r. u 66-letniego mężczyzny z woj. lubuskiego, który przyjechał 1 marca autokarem z Niemiec, gdzie prawdopodobnie doszło do zakażenia (9).

W tym czasie w krajach Europy zdiagnozowano już 4290 przypadków COVID-19 (dane na dzień 05.03.2020), z czego ponad 3 tys. we Włoszech i ponad 260 w Niemczech.

W ciągu czterech miesięcy, do 30 czerwca 2020 r, odnotowano w Polsce łącznie 34154 przypadki zakażenia, z czego 1444 osoby zmarły, podczas gdy w Europie całkowita liczba potwierdzonych przypadków przekroczyła 2 mln 400 tysięcy, a liczba zgonów wynosiła około 191 tysięcy (10).

Szybko rozwijający się ogólnoświatowy kryzys wymagał również działań pozwalających na bieżące monitorowanie sytuacji na poziomie międzynarodowym. Nadzór epidemiologiczny nad przypadkami COVID-19 od początku wykrycia ogniska w Chinach był organizowany i wspierany na poziomie globalnym przez WHO, we współpracy $\mathrm{z}$ organizacjami działającymi w poszczególnych regionach. Zgodnie z Rozporządzeniem WE 851/2004 Parlamentu Europejskiego i Rady kraje EU/EEA (oraz Wielka Brytania) są zobowiązane do przekazywania informacji dotyczących chorób zakaźnych poprzez właściwie, wskazane do tego przez kraj instytucje lub bezpośrednio przez władze kraju do ustanowionej w 1998 r. (decyzją 2119/98/WE PE i Rady) wspólnotowej sieci nadzoru i kontroli epidemiologicznej chorób zakaźnych.

Pod koniec stycznia 2020 r. został udostępniony przez ECDC pierwszy protokół raportowania przypadków COVID-19 do Europejskiej Sieci Nadzoru (TESSy, The European Surveillance System), w ciągu kolejnych miesięcy publikowano uaktualnione wersje protokołu (11).

Zgodnie z pierwszym protokołem raporty o zachorowaniach powinny być przekazywane do sieci euro- 
The ECDC reporting protocol included all the information included in the Case Reporting Form (12), published on January 22 by WHO, as well as a number of additional questions/variables.

The electronic system supporting epidemiological surveillance, designed and implemented in Poland, was intended not only to ensure the collection of information for national purposes at the poviat, voivodeship and central level, but also to enable the fulfillment of the obligation of timely reporting data to the European surveillance network. Therefore, it was necessary to create an additional module in the central system that would allow for the registration of suspected and confirmed cases of SARS-CoV-2 infections.

Later on, other systems for collecting information on COVID-19 were also created to support specific activities related to combating COVID-19, including the EWP system initially dedicated to quarantine and then expanded with a module enabling the coordinated referral and registration of COVID-19 tests, and the National Register of Patients with COVID-19 collecting clinical information about hospitalized patients. There are also aggregated reporting systems, mainly focused on use of medical resources.

\section{AIM AND METHODS}

The aim of this article is to present the COVID-19 module, created as part of the Epidemiological Case Reporting System (SRWE), which is a basic tool for work within the mandate of the Department of Epidemiology of Infectious Diseases and Surveillance of the National Institute of Public Health - National Institute of Hygiene (NIPH-NIH) (regarding epidemiological surveillance) and an initial evaluation of its usefulness for the purposes of fighting the pandemic.

The scope of the collected data and the purposes for which, due to the collected scope, these data can be used are described. As part of the evaluation, the completeness of the SRWE system was assessed in relation to the data published by the Ministry of Health on the number of cases and deaths related to COVID-19 reported in Poland. Data collected in the SRWE system was also analysed, summarizing delays in registering cases in the system. For this purpose, the percentage of cases registered in the system within 1 day, 2-3 days, 4-7 days and over 7 days from the diagnosis was used. Additionally, using analogous periods, the percentages of cases reported to the sanitary-epidemiological station from the diagnosis and the percentages registered in the SRWE from the date of notification were calculated. pejskiej jednostkowo w ciągu 24 godzin od wykrycia i zawierać kluczowe dane epidemiologiczne dotyczące przypadków prawdopodobnych i potwierdzonych, zaklasyfikowanych zgodnie z definicją przypadku dla celów nadzoru.

Protokół raportowania do ECDC zawierał wszystkie informacje uwzględnione $\mathrm{w}$ formularzu zgłoszeniowym Case Reporting Form (12), opublikowanym 22 stycznia przez WHO, oraz szereg dodatkowych pytań/ zmiennych.

Zaprojektowany i zaimplementowany w Polsce elektroniczny system wspierający działanie nadzoru epidemiologicznego miał $\mathrm{w}$ założeniu nie tylko zapewnić zbieranie informacji dla celów krajowych na szczeblu powiatowym, wojewódzkim i centralnym, ale również umożliwić wypełnienie obowiązku terminowego raportowania danych do europejskiej sieci nadzoru. Stąd też niezbędne było utworzenie dodatkowego modułu w centralnym systemie, który pozwalałby na rejestrację podejrzeń i potwierdzonych przypadków zakażeń SARS-CoV-2.

W późniejszym okresie powstały również inne systemy zbierania informacji o COVID-19 wspierające konkretne działania związane ze zwalczaniem COVID-19, w tym system EWP początkowo dedykowany kwarantannie a następnie rozbudowany o moduł umożliwiający skoordynowane zlecanie i rejestrację badań w kierunku COVID-19 oraz Krajowy Rejestr Pacjentów z COVID-19 zbierający informacje kliniczne o pacjentach hospitalizowanych. Istnieją również systemy raportowania zagregowanego, głownie w zakresie wykorzystania zasobów medycznych.

\section{CEL PRACY I METODY}

Celem pracy jest przedstawienie modułu COVID-19, który został utworzony w ramach Systemu Rejestracji Wywiadów Epidemiologicznych (SRWE), będącego podstawowym narzędziem pracy $w$ ramach działań Zakładu Epidemiologii Chorób Zakaźnych i Nadzoru NIZP-PZH dotyczących nadzoru epidemiologicznego oraz wstępna ewaluacja jego użyteczności do celów zwalczania pandemii.

Opisano zakres zbieranych danych i cele, do których w związku ze zbieranym zakresem te dane mogą zostać wykorzystane. W ramach ewaluacji oceniano kompletność systemu SRWE w odniesieniu do danych publikowanych przez Ministerstwo Zdrowia dot. liczby przypadków i zgonów na COVID-19 odnotowanych w Polsce. Przeanalizowano również dane zgromadzone w systemie SRWE, podsumowując opóźnienia rejestracji przypadków w systemie. W tym celu posłużono się odsetkiem przypadków zarejestrowanych w systemie w ciągu 1 dnia, 2-3 dni, 4-7 dni oraz powyżej 7 dni od rozpoznania. Dodatkowo obliczono odsetki przypadków zgłoszonych do stacji sanitarno-epidemiologicznej 


\section{EPIDEMIOLOGICAL CASE REPORTING SYSTEM DESCRIPTION}

\section{Aims and objectives of the Epidemiological} Case Reporting System. The electronic system was conceived to support the functioning of the Sanitary Inspection in the field of integrated documentation of actions taken (including procedures for contact persons and decisions on quarantine or epidemiological surveillance), while enabling timely collection of standardized epidemiological data. Standardization of data included the verification of case definition criteria used in epidemiological surveillance. A common definition was created for the European Union countries in order to compare the data. The system is designed to monitor the occurrence of COVID-19, including the severity of the clinical course (mortality), identify vulnerable groups and the circumstances of virus spread.

Initially, an expansion of the system was planned, with a module for hospitals with COVID-19 patients and a module for laboratories to document the results of SARS-CoV-2 testing. Ultimately, these functionalities were developed within other IT platforms (13), and work is currently underway to integrate these systems.

Case definition. At the beginning of the year 2020, WHO and ECDC published the first case definitions of infections with the new SARS-CoV-2 coronavirus (formerly 2019-nCoV). Since the publication of the first definitions, the guidelines for the classification of cases have been modified several times (14). These changes were introduced in line with the advances in knowledge about the new SARS-CoV-2 coronavirus.

The definition used in Poland from March 5, 2020 was created on the basis of the ECDC definition from March 2, 2020, which defined the clinical, epidemiological and laboratory criteria for the classification of suspected, probable, and confirmed cases

According to the Polish definition, any person showing symptoms such as fever, cough, shortness of breath, who returned from an area where there is local COVID-19 transmission or had close contact with a person who was infected, meets the criteria for suspected case. In addition, the criteria for a suspected case are also met by patients hospitalized with symptoms of severe respiratory infection without finding any other etiology fully explaining the clinical presentation.

A probable case is any person who meets the criteria for a suspected case and who has been tested positive for the presence of coronaviruses (pancoronavirus) by RT-PCR or an inconclusive result for the SARS-CoV-2 nucleic acid test. w ciągu analogicznych okresów od rozpoznania i odsetki zarejestrowanych w SRWE w ciągu analogicznych okresów od zgłoszenia.

\section{OPIS SYSTEMU REJESTRACJI WYWIADÓW EPIDEMIOLOGICZNYCH}

\section{Założenia i cele Systemu Rejestracji Wywiadów}

Epidemiologicznych. System elektroniczny miał wspomagać funkcjonowanie Inspekcji Sanitarnej w zakresie zintegrowanej dokumentacji podejmowanych działań (w tym ustaleń dotyczących osób z kontaktu z osobami chorymi oraz decyzji o kwarantannie lub objęciu nadzorem epidemiologicznym), umożliwiając jednocześnie terminowe zbieranie standaryzowanych danych epidemiologicznych. Standaryzacja danych m.in. obejmowała weryfikację kryteriów definicji przypadku stosowanej w nadzorze epidemiologicznym, ujednoliconej dla krajów Unii Europejskiej w celu porównywalności danych. System ma umożliwić monitorowania występowania COVID-19, w tym charakterystykę ciężkości przebiegu klinicznego (śmiertelność) oraz identyfikację narażonych grup i okoliczności szerzenia się wirusa.

Wstępnie planowano rozbudowę systemu o moduł dla szpitali, w których hospitalizowani są pacjenci z COVID-19 oraz moduł dla laboratoriów do dokumentowania wyników badań w kierunku SARS-CoV-2. Ostatecznie te funkcjonalności powstały w ramach innych platform informatycznych (13), a obecnie trwają prace nad integracją tych systemów.

Definicja przypadku. Na początku 2020 r. WHO oraz ECDC opublikowały pierwsze definicje przypadków zakażeń nowym koronawirusem SARS-CoV-2 (wcześniej 2019-nCoV). Wytyczne klasyfikacji przypadków zachorowań, od momentu opublikowania pierwszych definicji, kilkukrotnie uległy modyfikacjom (14). Zmiany te były wprowadzane zgodnie z postępem wiedzy na temat nowego koronawirusa SARS-CoV-2.

Definicja stosowana w Polsce od dnia 5 marca 2020 r. została stworzona na podstawie definicji ECDC z dnia 2 marca 2020 r., która określała kryteria kliniczne, epidemiologiczne oraz laboratoryjne do klasyfikacji podejrzeń przypadków, przypadków prawdopodobnych oraz przypadków potwierdzonych.

Według polskiej definicji, każda osoba wykazująca objawy takie jak gorączka, kaszel, duszność, która powróciła z obszaru, gdzie występuje lokalna transmisja COVID-19 lub miała bliski kontakt z osobą, u której stwierdzono zakażenie, spełnia kryteria podejrzenia przypadku. Ponadto, kryteria podejrzenia przypadku spełniają również osoby hospitalizowane $\mathrm{z}$ objawami ciężkiej infekcji układu oddechowego bez stwierdzenia innej etiologii w pełni wyjaśniającej obraz kliniczny.

Przypadek prawdopodobny to każda osoba, która spełnia kryteria podejrzenia przypadku oraz u której 
A case is classified as confirmed if SARS-CoV-2 nucleic acid is detected in the clinical material from a person suspected of infection and the result is confirmed by molecular testing targeted at a different area of the viral genome.

An updated version of the definition has been in force since June 16, 2020 (15) - compared to the previous version, the clinical criteria have been expanded to include sudden onset of anosmia, sudden ageusia or other taste disorder, and an imaging diagnostic criterion (changes in X-ray of the lungs indicating COVID -19). Residing (as a resident or staff member) in any care or long-term care facility where COVID-19 transmission has been confirmed has been added to the epidemiological criteria. Laboratory criteria for a probable case have been removed - after the change, any person meeting the clinical criteria and epidemiological criteria or meeting the diagnostic imaging criteria should be classified as a probable case.

The Epidemiological Case Reporting System. The nationwide electronic Epidemiological Case Reporting System (SRWE) was launched in 2016, it aimed at collecting data from individual epidemiological interviews conducted for disease cases under mandatory reporting to the epidemiological surveillance system based on the Act of 5 December 2008 on preventing and combating infections and human infectious diseases. Information on cases are registered via the system by employees of Poviat Sanitary and Epidemiological Stations (PSSE). The entered data is verified by the employees of Voivodeship Sanitary and Epidemiological Stations (WSSE) and employees of the Department of Epidemiology of Infectious Diseases and Surveillance of NIPH-NIH, after which they are periodically reported to the European Surveillance System (TESSy).

To work in the system, individual registration of each user is required, in which the scope of their access is specified. The general rule is that users from individual poviat and voivodship stations have access only to data from the area they supervise. Only poviat stations have the right to edit the interviews. Voivodship stations and the National Institute of Public Health - National Institute of Hygiene have read-only capacity and can submit their comments using the Comments function. Most of the variables in the system have dictionaries and automatic validations.

Initially, the system included electronic forms for cases of HBV and HCV infections. In the next stages, forms for giardiasis, Lyme disease, pertussis, intestinal salmonellosis, campylobacteriosis, yersiniosis, invasive pneumococcal disease, meningococcal otrzymano dodatni wynik badania RT-PCR w kierunku obecności koronawirusów (pan-coronavirus) lub wątpliwy wynik badania wykrywającego kwas nukleinowy SARS-CoV-2.

Przypadek jest klasyfikowany jako potwierdzony, jeśli w materiale klinicznym pobranym od osoby podejrzanej o zakażenie wykryto kwas nukleinowy SARSCoV-2 i wynik potwierdzono badaniem molekularnym ukierunkowanym na inny obszar genomu wirusa.

Od 16 czerwca 2020 r. obowiązuje zaktualizowana wersja definicji (15) - w porównaniu z wcześniejszą wersją kryteria kliniczne zostały rozszerzone o utratę węchu o nagłym początku, utratę lub zaburzenia smaku o nagłym początku oraz dodano kryterium diagnostyki obrazowej (zmiany w RTG płuc wskazujące na COVID-19). Do kryteriów epidemiologicznych dodano przebywanie (jako pensjonariusz lub członek personelu) w placówce opiekuńczej/opieki długoterminowej, w której potwierdzono transmisję COVID-19. Usunięto kryteria laboratoryjne przypadku prawdopodobnego po zmianie jako przypadek prawdopodobny powinna zostać zaklasyfikowana każda osoba spełniająca kryterium kliniczne oraz kryterium epidemiologiczne lub spełniająca kryterium diagnostyki obrazowej.

System Rejestracji Wywiadów Epidemiologicznych. Ogólnopolski elektroniczny System Rejestracji Wywiadów Epidemiologicznych (SRWE) został uruchomiony w 2016 r., miał na celu gromadzenie danych z indywidualnych wywiadów epidemiologicznych przeprowadzanych dla jednostek chorobowych obowiązkowo zgłaszanych do systemu nadzoru epidemiologicznego na podstawie Ustawy z dnia 5 grudnia 2008 r. o zapobieganiu oraz zwalczaniu zakażeń i chorób zakaźnych u ludzi. Informacje o przypadkach zachorowań są rejestrowane za pośrednictwem systemu przez pracowników Powiatowych Stacji Sanitarno-Epidemiologicznych. Wprowadzane dane są weryfikowane przez pracowników Wojewódzkich Stacji Sanitarno-Epidemiologicznych oraz pracowników Zakładu Epidemiologii Chorób Zakaźnych i Nadzoru NIZP-PZH, po czym są one cyklicznie raportowane do Europejskiego Systemu Nadzoru (The European Surveillance System, TESSy).

Do pracy w systemie wymagana jest indywidualna rejestracja każdego z użytkowników, w której określa się zakres jego uprawnień. Ogólnie obowiązuje zasada, że użytkownicy z poszczególnych stacji powiatowych i wojewódzkich mają dostęp jedynie do danych z obszaru przez nich nadzorowanego. Prawo do edycji wywiadów posiadają jedynie stacje powiatowe. Stacje wojewódzkie oraz Narodowy Instytut Zdrowia Publicznego - Państwowy Zakład Higieny posiadają dostęp do wglądu i mogą zgłaszać swoje uwagi za pomocą funkcjonalności Komentarze. Większość zmiennych w systemie posiada słowniki oraz automatyczne walidacje. 
disease, malaria, rubella, neuroinfection and HAV were added. In addition, data on exposure to rabies virus infection and subsequent post-exposure vaccinations are collected through the SRWE system. The system enables direct communication with the Registry of Epidemic Outbreaks, which collects data on outbreaks of foodborne diseases.

\section{SRWE MODULE - COVID-19}

In March 2020, a module on COVID-19 cases was made available in the SRWE. Work on the new case report form began at the beginning of February 2020 due to the increasing number of COVID-19 cases in China and around the world.

The COVID-19 case report form was created based on WHO guidelines for reporting confirmed and probable cases of 2019-nCoV (Interim case reporting form for 2019 Novel Coronavirus 2019-nCoV of confirmed and probable cases) and based on the ECDC requirements for reporting novel coronavirus cases to TESSy. Additionally, it is possible to register the epidemiological links between the cases along with a description of the circumstances of the contact and documentation of the actions taken.

Data on COVID-19 cases recorded in the SRWE include detailed data on infected or exposed persons, to the extent provided for in Article 30 (regarding the register of infectious diseases) of the Act of December 5, 2008 on preventing and combating infections and infectious diseases in humans. The form encompasses data from several key areas:

- Patient/contact data and system data: including basic demographic data (gender, age, occupation, place of residence), case classification, information source, station and registrant details.

- Data on the disease course: such as date of first symptoms onset, date of first medical consultation, date of diagnosis, data on hospitalization or isolation, symptoms (broad catalog, including non-specific symptoms, not mentioned in the case definition), coexisting diseases, course of the disease, outcome.

- Diagnostic laboratory tests: with the option to choose the type of SARS-CoV-2 test from among those approved for COVID-19 diagnostics and indicate the laboratory performing the tests.

- Epidemiological interview: extensive section with questions to determine the circumstances of exposure, contact with other people infected with SARS-CoV-2, travel history during the 14 days before symptom onset, details of contact cases, stays in health care facilities, etc.
Początkowo system obejmował formularze elektroniczne dla przypadków zakażeń HBV oraz HCV. W kolejnych etapach zostały dodane formularze dla giardiozy, boreliozy, krztuśca, salmonellozy jelitowej, kampylobaketriozy, jersiniozy, inwazyjnej choroby pneumokokowej, choroby meningokokowej, malarii, różyczki, neuroinfekcji i HAV. Ponadto, poprzez system SRWE zbierane są dane dotyczące narażeń na zakażenie wirusem wścieklizny, po których podjęto decyzję o konieczności wykonania szczepień poekspozycyjnych. System umożliwia bezpośrednią komunikację z Rejestrem Ognisk Epidemicznych, w którym zbierane są dane dotyczące ognisk chorób przenoszonych drogą pokarmową.

\section{MODUŁ SRWE - COVID-19}

W marcu 2020 r. w SRWE udostępniono moduł dotyczący zachorowań na COVID-19. Prace nad nowym formularzem zaczęły się na początku lutego $2020 \mathrm{r}$. w związku z narastającą liczbą zachorowań na COVID-19 w Chinach i na świecie.

Formularz COVID-19 został stworzony w oparciu o wytyczne WHO do raportowania potwierdzonych i prawdopodobnych przypadków 2019-nCoV (Interim case reporting form for 2019 Novel Coronavirus 2019$\mathrm{nCoV}$ of confirmed and probable cases) oraz $\mathrm{w}$ oparciu o wymagania ECDC dotyczące raportowania przypadków nowego koronawirusa do TESSy. Dodatkowo możliwa jest rejestracja powiązań epidemiologicznych pomiędzy przypadkami wraz z opisem okoliczności kontaktu oraz dokumentacja podjętych działań.

Dane dotyczące zachorowań na COVID-19 rejestrowane w SRWE obejmują dane szczegółowe o osobach chorych lub narażonych, w zakresie przewidzianym w Art. 30 (dot. rejestru chorób zakaźnych) Ustawy z dn. 5 grudnia 2008 r. o zapobieganiu oraz zwalczaniu zakażeń i chorób zakaźnych u ludzi. Formularz zawiera dane z kilku najważniejszych obszarów:

- Dane o chorym/narażonym oraz dane systemowe: $\mathrm{m}$. in. podstawowe dane demograficzne (płeć, wiek, zawód, miejsce zamieszkania), klasyfikacja przypadku, źródło informacji, dane stacji i osoby rejestrującej.

- Dane o zachorowaniu: m.in. data wystąpienia pierwszych objawów, data zgłoszenia się do lekarza, data rozpoznania, dane dotyczące hospitalizacji lub izolacji, objawy (szeroki katalog z uwzględnieniem objawów niespecyficznych, niewymienionych w definicji przypadku), choroby wspólistniejące, przebieg choroby, zejście.

- Diagnostyczne badania laboratoryjne: z możliwością wyboru rodzaju badania w kierunku SARSCoV-2 spośród dopuszczonych do diagnostyki CO- 
- Actions taken: including information about decisions to place exposed persons under surveillance or quarantine, and on their end dates. The COVID-19 form, since its introduction, has been modified due to changing guidelines and newly emerging information about the transmission of the virus. An example is the removal of the section on exposure to animals.

The form registers people who show symptoms that meet the criteria for a suspected, probable or confirmed case according to the definition. In addition, asymptomatic people who are close contacts of probable or confirmed COVID-19 cases under surveillance are also recorded. It is also possible to enter information about persons under surveillance who do not meet any of the above criteria (e.g. contact persons not considered close contacts, persons with mild symptoms of respiratory system infection reporting to the station or to their primary healthcare, for whom self-monitoring was recommended) - this action was introduced to facilitate and expedite the transfer of data when changing status from a person under observation to a case that meets the definition criteria of a probable or confirmed case. Currently, quarantined persons are registered in the EWP system (16), therefore this functionality is generally not used.

Data on COVID-19 collected in the SRWE are monitored on an ongoing basis and subject to initial verification by the employees of the Department of Epidemiology of Infectious Diseases and Surveillance of the NIPH-NIH. The system allows you to add comments to individual interviews in order to clarify or draw attention to inaccuracies appearing in the interview. Comments can be added by users from any level (PSSE, WSSE, NIPH-NIH) and are divided into 3 categories - optional, important and critical. As of June 30, 2020, 3346 comments have been added to COVID-19 reports.

Reporting to international institutions. Despite the limitations described below, the SRWE remains the system from which individual data on COVID-19 cases in Poland is reported, due to the widest range of epidemiological data collected by this system.

The obligation to report confirmed and probable cases of COVID-19 through the European Surveillance System TESSy was introduced on January 27, 2020. Reports on new cases were to be sent within 24 hours of the detection of the case. Reporting through the TESSy system also fulfills the obligation to report cases to the WHO, as the data collected in the European Surveillance System is relayed to the WHO EURO Regional Office.

Employees of the Department of Epidemiology of Infectious Diseases and Surveillance of the NIPH-
VID-19 oraz zaznaczenia laboratorium wykonującego badania.

- Wywiad epidemiologiczny: obszerna sekcja zawierająca pytania pozwalające ustalić okoliczności narażenia, kontakty z osobami zakażonymi SARSCoV-2, przebywanie poza miejscem zamieszkania w okresie 14 dni przed zachorowaniem, dane osób ze styczności z chorym, pobyty w placówkach opieki zdrowotnej i in.

- Podjęte działania: w tym m.in. decyzje o objęciu nadzorem lub kwarantanną osób narażonych oraz czas zakończenia nadzoru lub kwarantanny.

Formularz COVID-19, od momentu wprowadzenia, był modyfikowany ze względu na zmieniające się wytyczne oraz nowo pojawiające się informacje dotyczące szerzenia się wirusa. Przykładem jest usunięcie części dotyczącej narażenia na kontakt ze zwierzętami.

W formularzu rejestrowane są osoby wykazujące objawy chorobowe, które spełniają kryteria podejrzenia, przypadku prawdopodobnego lub przypadku potwierdzonego zgodnie z definicją. Dodatkowo, rejestrowane są również osoby bezobjawowe $\mathrm{z}$ bliskiego kontaktu z przypadkiem prawdopodobnym lub potwierdzonym COVID-19 objęte nadzorem. Możliwe jest również wprowadzanie informacji o osobach objętych nadzorem, nie spełniających żadnych z powyższych kryteriów (np. osoby z kontaktu nie uznawanego za bliski kontakt, osoby z łagodnymi objawami infekcji układu oddechowego zgłaszające się do stacji lub POZ, którym zalecono samoobserwację) - działanie to zostało wprowadzone w celu ułatwienia i przyspieszenia przekazywania danych w momencie zmiany statusu z osoby pod nadzorem na przypadek spełniający kryteria przypadku prawdopodobnego lub potwierdzonego zgodnie $\mathrm{z}$ definicją. Obecnie osoby poddane kwarantannie są rejestrowane w systemie EWP (16), w związku z czym ta funkcjonalność pozostaje na ogół niewykorzystywana.

Dane dotyczące COVID-19 gromadzone w SRWE są na bieżąco monitorowane i poddawane wstępnej weryfikacji przez pracowników Zakładu Epidemiologii Chorób Zakaźnych i Nadzoru NIZP-PZH. System pozwala na dodawanie komentarzy do poszczególnych wywiadów w celu wyjaśnienia lub zwrócenia uwagi na nieścisłości pojawiające się w wywiadzie. Komentarze mogą być dodawane przez użytkowników z każdego poziomu (PSSE, WSSE, NIZP-PZH) i są podzielone na 3 kategorie - opcjonalne, ważne oraz krytyczne. Na dzień 30 czerwca 2020 r. w systemie dodano 3346 komentarzy do wywiadów COVID-19.

Raportowanie do instytucji międzynarodowych. Pomimo ograniczeń opisanych poniżej SRWE pozostaje systemem, z którego przekazywane są dane indywidualne dotyczące zachorowań na COVID-19 w Polsce, z powodu najszerszego zakresu danych epidemiologicznych zbieranych przez ten system. 
NIH prepare data for the TESSy system regarding new cases of COVID-19 (confirmed and probable) registered in the SRWE system every 24 hours. As of June 30, 2020, 118 such reports were prepared and submitted. The first case recorded in Poland was reported to TESSy on March 4, 2020.

Data completeness. The first case of COVID-19 was entered into the SRWE system on March 4, 2020. Until June 28, the system had 27906 interviews recorded, including 14144 classified as confirmed cases, 207 as probable cases and 4829 as suspected cases.

The completeness of the number of probable and confirmed COVID-19 cases registered in the SRWE compared to the data on the number of diagnoses collected independently by the Ministry of Health (Ministry of Health) is approximately $42 \%$. The completeness of the number of cases by voivodship is presented in the table (Tab. I).
Obowiązek raportowania potwierdzonych i prawdopodobnych przypadków COVID-19 poprzez Europejski System Nadzoru TESSy został wprowadzony w dniu 27 stycznia 2020 r. Raporty o nowych zachorowaniach powinny być przesłane w ciągu 24 godzin od wykrycia przypadku. Raportowanie poprzez system TESSy wypełnia również obowiązek raportowania przypadków do WHO, gdyż dane gromadzone w europejskim systemie nadzoru są przekazywane do Biura Regionalnego WHO EURO.

Pracownicy Zakładu Epidemiologii Chorób Zakaźnych i Nadzoru NIZP-PZH w ciągu każdych kolejnych 24 godzin przygotowują dane do systemu TESSy dotyczące nowych przypadków COVID-19 (potwierdzonych i prawdopodobnych) zarejestrowanych w systemie SRWE. Na dzień 30 czerwca 2020 r. przygotowano i przekazano 118 takich raportów. Pierwszy przypadek odnotowany w Polsce został zaraportowany do TESSy w dniu 4 marca 2020 r.

Kompletność danych. Pierwszy przypadek COVID-19 wprowadzono do systemu SRWE w dniu 4 marca 2020 r. Do dnia 28 czerwca w systemie zarejestrowano 27906 wywiadów, w tym 14144 sklasyfikowanych jako przypadki potwierdzone, 207 jako przypadki prawdopodobne oraz 4829 jako podejrzenia przypadku.

Kompletność liczby zarejestrowanych w SRWE prawdopodobnych oraz potwierdzonych przypadków COVID-19 w porównaniu z danymi dotyczącymi licz-

Table I. Completeness of registering COVID-19 cases in the SRWE system by voivodship (17).

Tabela I. Kompletność rejestrowania przypadków COVID-19 w systemie SRWE wg województw (17).

\begin{tabular}{|c|c|c|c|c|c|c|}
\hline \multirow[b]{2}{*}{ Województwo } & \multicolumn{2}{|c|}{ Dane MZ na 28.06.2020 (17) } & \multicolumn{4}{|c|}{ Dane SRWE na 28.06.2020 } \\
\hline & $\begin{array}{c}\text { Liczba } \\
\text { przypadków }\end{array}$ & Zgony & $\begin{array}{c}\text { Liczba } \\
\text { przypadków }\end{array}$ & $\%$ & $\begin{array}{c}\text { Zgony z } \\
\text { powodu } \\
\text { COVID-19 }\end{array}$ & $\%$ \\
\hline Dolnośląskie & 2910 & 139 & 1843 & $63 \%$ & 58 & $42 \%$ \\
\hline Kujawsko-Pomorskie & 669 & 49 & 596 & $89 \%$ & 44 & $90 \%$ \\
\hline Lubelskie & 642 & 17 & 528 & $82 \%$ & 16 & $94 \%$ \\
\hline Lubuskie & 149 & 0 & 85 & $57 \%$ & 0 & - \\
\hline Łódzkie & 3086 & 161 & 1205 & $39 \%$ & 60 & $37 \%$ \\
\hline Małopolskie & 1685 & 44 & 1350 & $80 \%$ & 36 & $82 \%$ \\
\hline Mazowieckie & 4975 & 326 & 2153 & $43 \%$ & 122 & $37 \%$ \\
\hline Opolskie & 932 & 51 & 370 & $40 \%$ & 15 & $29 \%$ \\
\hline Podkarpackie & 635 & 50 & 408 & $64 \%$ & 31 & $62 \%$ \\
\hline Podlaskie & 806 & 10 & 217 & $27 \%$ & 4 & $40 \%$ \\
\hline Pomorskie & 657 & 38 & 619 & $94 \%$ & 36 & $95 \%$ \\
\hline Śląskie & 12524 & 319 & 2889 & $23 \%$ & 70 & $22 \%$ \\
\hline Świętokrzyskie & 776 & 38 & 243 & $31 \%$ & 13 & $34 \%$ \\
\hline Warmińsko-mazurskie & 240 & 1 & 212 & $88 \%$ & 1 & $100 \%$ \\
\hline Wielkopolskie & 2612 & 175 & 1392 & $53 \%$ & 34 & $19 \%$ \\
\hline Zachodniopomorskie & 609 & 20 & 241 & $40 \%$ & 4 & $20 \%$ \\
\hline SUMA & 33907 & 1438 & 14351 & $42 \%$ & 544 & $38 \%$ \\
\hline
\end{tabular}


The comparison of the number of cases registered in the SRWE with the data of the Ministry of Health presented above indicates sizable underreporting of cases in the central system.

The completeness of the registered cases by date of diagnosis in comparison with the $\mathrm{MoH}$ data is presented in the diagram (Fig. 1). If the date of diagnosis was missing, the date of the laboratory test result was assumed as the date of case diagnosis. As of June 28, 2020, neither the date of diagnosis nor the date of the result has been completed for 1291 probable and confirmed cases. The chart below shows that there were cases diagnosed even at the end of March and at the beginning of April, which have not yet been completed in the SRWE system. by rozpoznań zbieranych niezależnie przez Ministerstwo Zdrowia (MZ) wynosi około $42 \%$ Kompletność liczby przypadków według województw przedstawiono w tabeli (Tab. I).

Przedstawione powyżej porównanie liczby przypadków zarejestrowanych w SRWE z danymi MZ wskazuje na duże niedorejestrowanie przypadków w systemie centralnym.

Kompletność zarejestrowanych przypadków według daty rozpoznania $\mathrm{w}$ porównaniu $\mathrm{z}$ danymi MZ przedstawiono na wykresie (Ryc. 1). W przypadku braku daty rozpoznania, przyjęto datę wyniku badania laboratoryjnego jako datę rozpoznania przypadku. Na dzień 28.06.2020 r. nie uzupełniono ani daty rozpoznania ani daty wyniku dla 1291 przypadków prawdopodobnych i potwierdzonych. Poniższy wykres wskazuje na to, że są przypadki rozpoznane nawet pod koniec marca i na początku kwietnia, które nie zostały jeszcze uzupełnione w systemie SRWE.

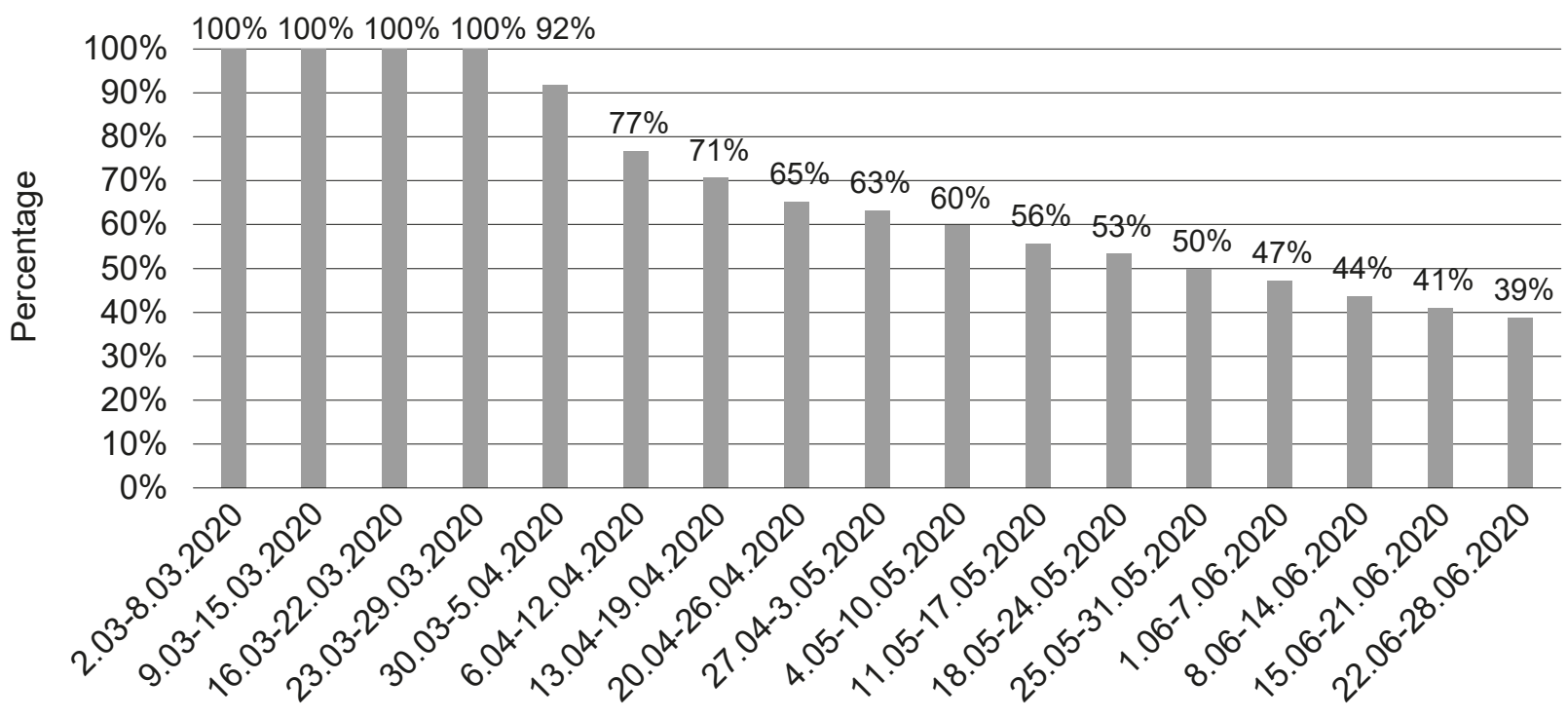

Week

Fig. 1. Proportion of registered COVID-19 cases in the SRWE by the date of diagnosis/result in relation to the data presented by the Ministry of Health in the period $01.03-28.06 .2020$ (as of 28.06.2020).

Ryc. 1. Proporcja zarejestrowanych przypadków COVID-19 w SRWE według daty rozpoznania/wyniku w stosunku do danych prezentowanych przez MZ w okresie od 1.03-28.06.2020 r. (stan na dzień 28.06.2020).

Reporting delays. Based on the analysis of data included in the interviews introduced in the initial period of the COVID-19 epidemic in Poland, it can be observed that the vast majority of registered cases (over $80 \%$ ) were reported to the station by doctors and laboratories within one day from the date of diagnosis of the infection (Fig. 2). The time needed to enter information about a given case into the system, both from the date of diagnosis of the infection and from the date of the first reporting to the station, was usually more than 7 days, the percentage of such
Opóźnienie w rejestracji. Na podstawie analizy danych zawartych w wywiadach wprowadzonych w początkowym okresie epidemii COVID-19 w Polsce, można zauważyć, że zdecydowana większość zarejestrowanych przypadków (ponad 80\%) została zgłoszona do stacji przez lekarzy i laboratoria w okresie do jednego dnia od daty rozpoznania zakażenia (Ryc. 2). Czas potrzebny na wprowadzenie informacji o danym przypadku do systemu, zarówno od daty rozpoznania zakażenia jak i od daty pierwszego zgłoszenia do stacji wynosił najczęściej powyżej 7 dni, odsetek takich przypadków wynosił odpowiednio ok. 57\% i 66\% (Ryc. 3, Ryc. 4). 
cases was approx. $57 \%$ and $66 \%$, respectively (Fig. 3, Fig. 4).

Therefore, it can be concluded that most of the delays $(>55 \%)$ occur at the station, i.e. after the case is reported by a doctor or a laboratory (Fig. 2-4). The delays are mainly caused by the excessive workload of the station employees with other tasks related to COVID-19, including a large number of various analyses and reports prepared at the request of various entities and institutions.
Można zatem stwierdzić, iż do większości opóźnień $(>55 \%)$ dochodzi po stronie stacji, tj. już po zgłoszeniu przypadku przez lekarza lub laboratorium (Ryc. 2-4). Opóźnienia spowodowane są głównie nadmiernym obciążeniem pracowników stacji innymi zadaniami związanymi z COVID-19, w tym dużą liczbą różnych zestawień i raportów przygotowywanych na zlecenie różnych podmiotów i instytucji.

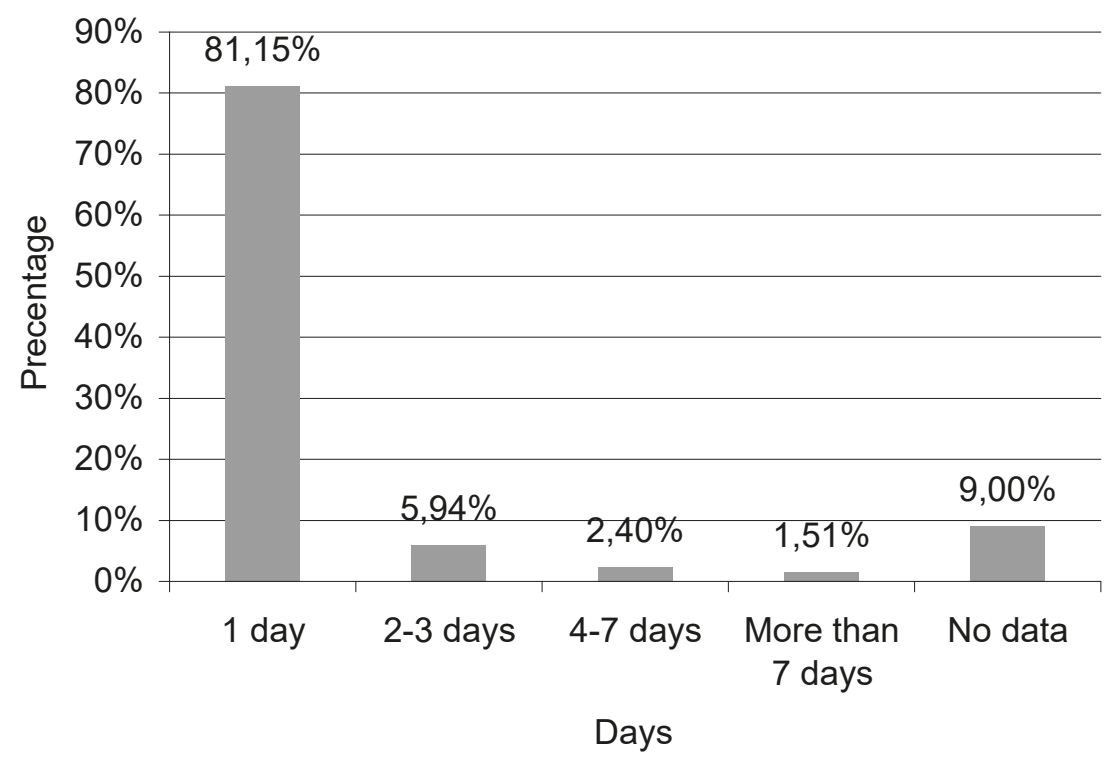

Fig. 2. Percentage of cases reported by doctors/laboratories to sanitary-epidemiological stations within one, 2-3 days, 4-7 days and more than 7 days from diagnosis.

Ryc. II. Odsetek przypadków zgłoszonych przez lekarzy/laboratoria do stacji sanitarno-epidemiologicznych w okresie do jednego, 2-3 dni, 4-7 oraz powyżej 7 dni od rozpoznania.

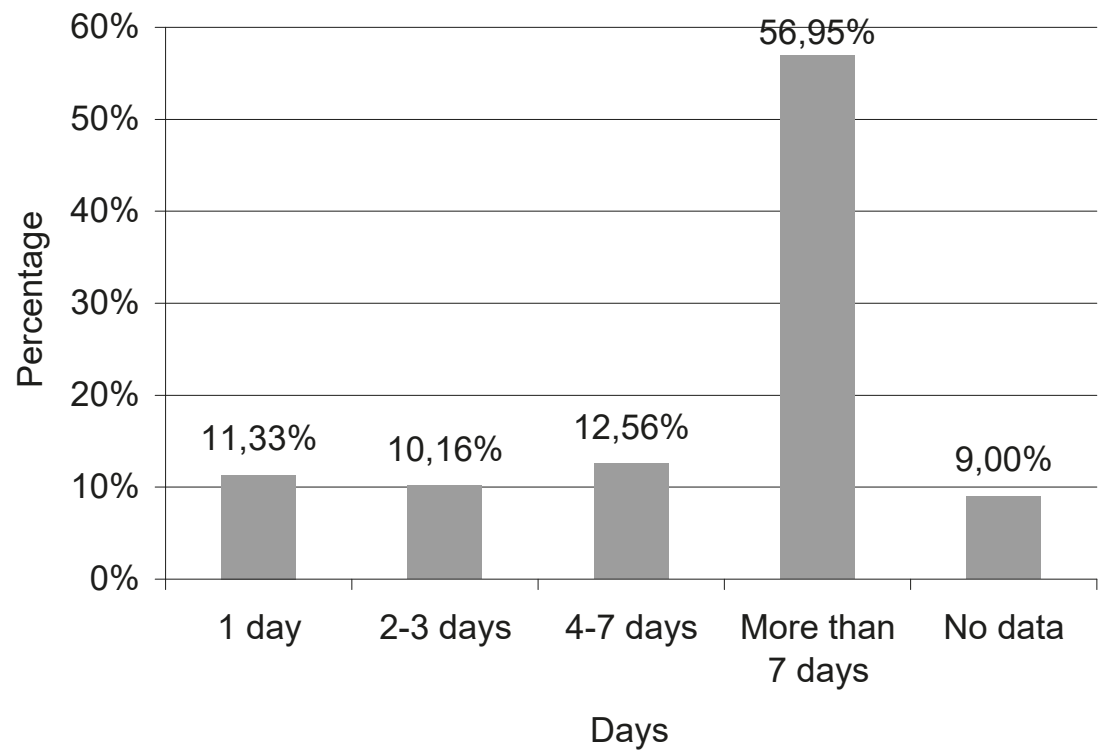

Fig. 3. Percentage of cases registered in the SRWE by sanitary-epidemiological stations within one, 2-3 days, 4-7 days and more than 7 days from the diagnosis

Ryc. 3. Odsetek przypadków zarejestrowanych w SRWE przez stacje sanitarno-epidemiologiczne w okresie do jednego, 2-3 dni, 4-7 oraz powyżej 7 dni od rozpoznania 


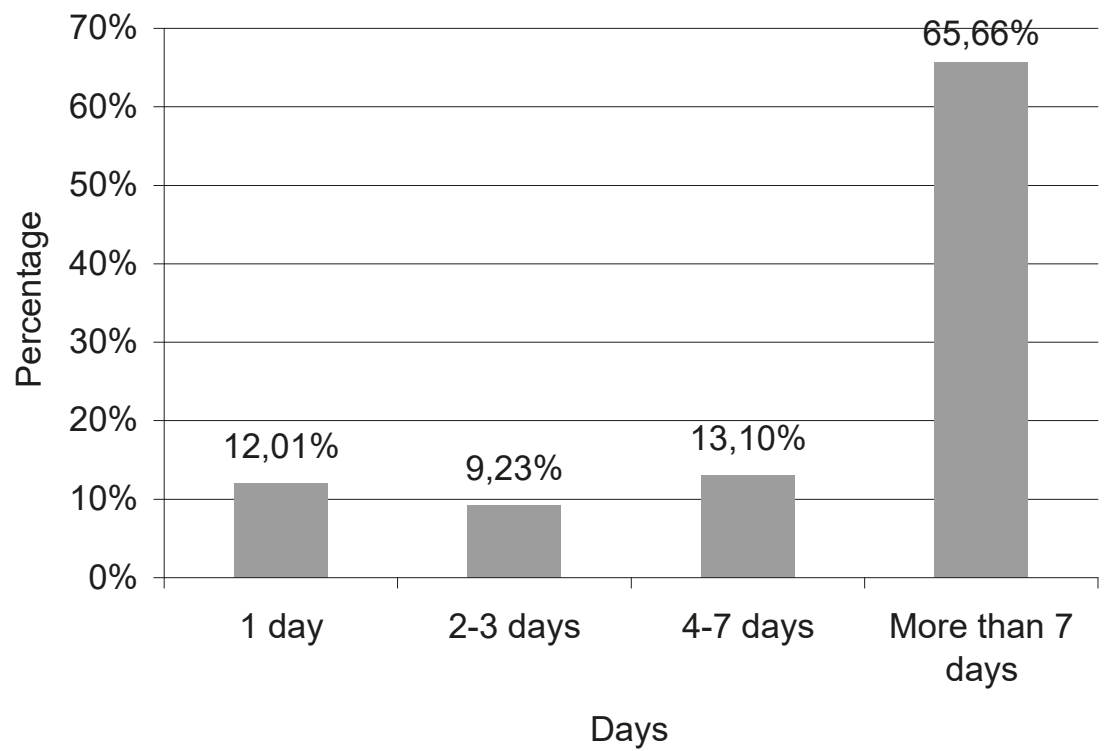

Fig. 4. Percentage of cases registered in the SRWE by sanitary-epidemiological stations within one, 2-3 days, 4-7 days and more than 7 days from reporting to the station

Ryc. 4. Odsetek przypadków zarejestrowanych w SRWE przez stacje sanitarno-epidemiologiczne w okresie do jednego, 2-3 dni, 4-7 oraz powyżej 7 dni od zgłoszenia do stacji

Possibilities of data utilization. Despite delays in registering individual data, the COVID-19 module fulfills the role of a tool to achieve the basic goals of ongoing surveillance - it allows, though not in real-time, for monitoring the incidence trend and geographical spread of COVID-19 infections. The system facilitates the detection of outbreaks by identifying patients working in the same places, attending the same educational institutions, or with history of being in a health care facility, as well as by detecting geographically grouped cases. Additionally, it is possible to identify risk groups and disease trends in these groups, e.g. monitoring the number of infected health care workers and the effectiveness of the measures taken to contain the spread of infections. By monitoring the percentage of people hospitalized and undergoing mechanical ventilation, as well as the average length of hospitalization, it is possible to assess the impact of disease on the burden on the healthcare system.

Currently, as part of an epidemiological inquiry, it is possible to identify the index case in small family outbreaks, trace the chain of infection and document the cases in the system. In the case of a larger group of people (e.g. in a workplace) it is difficult to recreate the entire chain of infections, hence it would be necessary to record the outbreak. In the case of infections of healthcare professionals, it was not clear at the system design stage that detailed monitoring of the spread of infections would be necessary due to exposure of healthcare professionals and patients in healthcare settings. Currently, the system can monitor infections in healthcare professionals based
Możliwości wykorzystania danych. Pomimo opóźnień w rejestracji danych indywidualnych moduł COVID-19 spełnia rolę narzędzia do realizacji podstawowych celów nadzoru bieżącego - pozwala, choć niestety nie w czasie rzeczywistym, na monitorowanie trendu zapadalności oraz geograficznego rozpowszechnienia zakażeń COVID-19. System ułatwia wykrywanie ognisk poprzez możliwość identyfikacji chorych pracujących w tych samych instytucjach, uczęszczających do tych samych placówek oświatowych, czy z wywiadem pobytu w placówce opieki zdrowotnej a także poprzez wykrycie zgrupowanych geograficznie zachorowań. Dodatkowo możliwe jest identyfikowanie grup ryzyka i trendów zachorowań w tych grupach, m.in. monitorowanie liczby zakażonych pracowników ochrony zdrowia oraz skuteczność zastosowanych środków powstrzymujących szerzenie się zakażeń. Poprzez monitorowanie odsetka osób hospitalizowanych oraz poddawanych mechanicznej wentylacji, a także średniego czasu hospitalizacji można dokonać oceny wpływu zachorowań na obciążenie systemu opieki zdrowotnej.

Obecnie $w$ ramach dochodzenia epidemiologicznego możliwe jest wyznaczenie przypadku indeksowego w małych rodzinnych ogniskach, prześledzenie łańcucha szerzenia się zakażeń oraz udokumentowanie przypadków w systemie. W przypadku większej grupy osób (np. w zakładzie pracy) trudno jest odtworzyć cały łańcuch zakażeń, stąd konieczna byłaby możliwość oznaczenia ogniska. W przypadku zakażeń personelu medycznego na etapie projektowania systemu nie było jasne, że będzie konieczne szczegółowe monitorowanie szerzenia się zakażeń $\mathrm{w}$ związku $\mathrm{z}$ narażeniami personelu i pacjentów w placówkach służby zdrowia. 
on a combined analysis of the profession and exposure circumstances, but the system allows for the addition of new variables to better describe the spread of infections in medical facilities.

The data collected in the SRWE, in addition to their primary purpose related to the assessment of the current epidemiological situation in Poland and EU countries and the assessment of disease severity in Poland, can provide a lot of information for the estimation of the actual, current and predicted number of COVID-19 cases. On the basis of the data recorded in the system, it is possible, for example, to determine the percentage of people who have already fallen ill but have not yet sought out a doctor (delay between the onset of symptoms and the date of reporting to the doctor), the percentage of people who will be reported late or the delay resulting from the waiting time for the test result. Such data analysis may allow for targeted measures to reduce the spread of the disease in the population.

Limited possibility of reporting individual case data due to a large number of new cases is a situation that has been anticipated by the ECDC in the documents "Rapid Risk Assessment Novel coronavirus disease 2019 (COVID-19) pandemic: increased transmission in the EU/EEA and the UK - sixth update" from March 12, 2020 (18) and the "Strategies for the surveillance of COVID-19" of April 9, 2020 (19). In the event of a very heavy burden and capacity saturation of the epidemiological surveillance system, the last possible scenario is to report the number of confirmed and the number of samples tested in the form of aggregated data.

A detailed analysis of the data contained in the interviews recorded in the SRWE will be the subject of a separate publication.

System limitations. Delays in registering cases are a significant limitation of the system. With the rapidly increasing daily number of cases and numerous obligations imposed on sanitaryepidemiological stations, delays in registration are inevitable and are likely to keep gradually extending. Currently, part of the station's work is duplicated due to the requirements for reporting data on the same cases to various institutions and authorities at local, regional and national levels. Integration of operating systems would allow to relieve station staff and would also contribute to the improvement of data quality.

Another significant limitation is the inability to register epidemic outbreaks. The SRWE currently does not allow easy tracking of large SARS-CoV-2 virus outbreaks. The possibility of marking cases as belonging to certain outbreaks in the SRWE system and creating a central register of outbreaks would
Obecnie w systemie istnieje możliwość monitorowania zakażeń personelu medycznego na podstawie połączonej analizy wykonywanego zawodu oraz okoliczności narażenia, jednak system pozwala na dodanie nowych zmiennych lepiej opisujących szerzenie się zakażeń w placówkach medycznych.

Dane gromadzone w SRWE, oprócz ich podstawowego przeznaczenia związanego $\mathrm{z}$ oceną bieżącej sytuacji epidemiologicznej w Polsce i krajach EU oraz oceną przebiegu zachorowań w Polsce, mogą dostarczyć wielu danych do estymacji rzeczywistej, bieżącej oraz prognozowanej liczby przypadków COVID-19. Na podstawie danych zarejestrowanych w systemie można np. określić odsetek osób, które już zachorowały, ale jeszcze nie zgłosiły się do lekarza (opóźnienie pomiędzy datą wystąpienia objawów a datą zgłaszania się do lekarza), odsetek osób, które zostaną zgłoszone z opóźnieniem lub określić opóźnienie wynikające z czasu oczekiwania na wynik badania. Taka analiza danych może pozwolić na ukierunkowane podjęcie działań ograniczających szerzenie się zachorowań w populacji.

Sytuacje ograniczenia możliwości raportowania pełnych danych jednostkowych w związku z dużą liczbą nowych przypadków zostały przewidziane przez ECDC w dokumentach "Rapid Risk Assessment Novel coronavirus disease 2019 (COVID-19) pandemic: increased transmission in the EU/EEA and the UK - sixth update" z 12 marca 2020 r. (18) oraz "Strategies for the surveillance of COVID-19” z 09 kwietnia 2020 r. (19). W przypadku bardzo dużego, na granicy wydolności obciążenia systemu nadzoru epidemiologicznego ostatnim możliwym scenariuszem jest raportowanie liczby przypadków potwierdzonych oraz liczby zbadanych próbek w postaci danych zagregowanych.

Szczegółowa analiza danych zawartych w wywiadach zarejestrowanych w SRWE będzie przedmiotem odrębnej publikacji.

Ograniczenia systemu. Znacznym ograniczeniem systemu są opóźnienia w rejestracji przypadków. Przy szybko wzrastającej dziennej liczbie przypadków oraz licznych obowiązkach nałożonych na stacje sanitarno -epidemiologiczne, opóźnienia w rejestracji są nieuniknione i prawdopodobnie będą się stopniowo wydłużać. Obecnie część pracy stacji jest powielona ze względu na wymagania dotyczące raportowania informacji na temat tych samych przypadków do różnych instytucji i podmiotów na szczeblach lokalnych, regionalnych i krajowych. Integracja funkcjonujących systemów pozwoliłaby na odciążenie pracowników stacji i przyczyniłaby się również do poprawy jakości danych.

Kolejnym istotnym ograniczeniem jest brak możliwości rejestracji ognisk epidemicznych. SRWE obecnie nie pozwala na łatwe śledzenie dużych ognisk zakażeń wirusem SARS-CoV-2. Możliwość oznaczenia przypadków jako należących do konkretnych ognisk 
allow better detection, monitoring and analysis of COVID-19 outbreaks occurring in the country.

The COVID-19 report form should be updated and expanded based on the latest available knowledge about the SARS-CoV-2 virus and COVID-19 disease. At the moment, elements concerning exposure of staff and patients in healthcare facilities should be expanded. Adding information about re-infections with coronavirus detected in convalescents, i.e. the occurrence of the so-called reinfection, should also be taken into account.

\section{CONCLUSIONS}

Based on the experience related to the preparation and functioning of the COVID-19 module during the first months of the epidemic in Poland, it can be concluded that the existing epidemiological case reporting system is an efficient and adequate tool also in the case of newly emerging threats. The system allows for quick creation of a new form for data collection and its adaptation to changing requirements, also permitting transfer of data to international institutions. Initial analyses of the functioning of the system and the collected data indicate the need to improve the system with the possibility of recording disease outbreaks, especially in health care facilities. Such a functionality seems to be crucial especially in the case of new threats from infectious diseases that spread through human-human transmission.

The creation and implementation of the COVID-19 module in the SRWE system was possible at the very beginning of the epidemic thanks to the existence of an interdisciplinary, experienced team of experts in the field of epidemiology of infectious diseases in the Department of Epidemiology of Infectious Diseases and Surveillance of the NIPH-NIH, analysts specialists in creating IT systems, and programmers. COVID-19 is a new disease and much information about it is still unknown or poorly understood. Due to the advancement of knowledge about this disease and its pathogen, as well as the continuing development of the epidemic in Poland, it is necessary to adapt and modify the SRWE system on an ongoing basis in accordance with current knowledge.

The assessment of the completeness of the number of recorded interviews in comparison with the official data of the Ministry of Health on new cases of SARS-CoV-2 infections does not allow the COVID-19 module to be considered a sufficient tool for monitoring the current epidemiological situation due to the delays in entering data into the system, but the collected information on cases will be an important source of data for analyses summarizing the course of the epidemic at a later date. w systemie SRWE oraz utworzenie centralnego rejestru ognisk pozwoliłoby lepiej wykrywać, monitorować oraz analizować ogniska zachorowań na COVID-19 pojawiających się w kraju.

Formularz dotyczący COVID-19 powinien zostać uaktualniony i rozbudowany w oparciu o najnowszą dostępną wiedzę na temat wirusa SARS-CoV-2 i zachorowaniach COVID-19. Na chwilę obecną, rozbudowana powinna zostać część dot. narażeń personelu i pacjentów w placówkach opieki zdrowotnej. Rozważyć też należy sposób monitorowania $\mathrm{w}$ systemie ponownych zakażeń koronawirusem wykrytych u ozdrowieńców, czyli wystąpienia tzw. reinfekcji.

\section{WNIOSKI}

Na podstawie doświadczeń związanych z przygotowaniem oraz funkcjonowaniem modułu COVID-19 w ciągu pierwszych miesięcy epidemii w Polsce, można stwierdzić, że istniejący system rejestracji wywiadów epidemiologicznych jest sprawnym i adekwatnym narzędziem również $\mathrm{w}$ przypadku nowo pojawiających się zagrożeń. System umożliwia szybkie wytworzenie nowego formularza do gromadzenia danych oraz jego dostosowanie do zmieniających się wymagań, również w związku z transferem danych do instytucji międzynarodowych. Wstępne analizy funkcjonowania systemu i zgromadzonych danych wskazują na potrzebę udoskonalenia systemu o możliwość oznaczania ognisk zakażeń, szczególnie występujących w placówkach opieki zdrowotnej. Taka funkcjonalność wydaje się kluczowa zwłaszcza w przypadku nowych zagrożeń ze strony chorób zakaźnych, które szerzą się na drodze człowiek - człowiek.

Utworzenie i zaimplementowanie modułu COVID-19 w systemie SRWE już na samym początku epidemii było możliwe dzięki istnieniu w Zakładzie Epidemiologii Chorób Zakaźnych i Nadzoru NIZP -PZH interdyscyplinarnego, doświadczonego zespołu składającego się z osób merytorycznych w zakresie epidemiologii chorób zakaźnych, analityków - specjalistów w zakresie budowy systemów informatycznych oraz programistów. COVID-19 jest nową chorobą i wiele informacji jej dotyczących jest ciągle nieznanych lub słabo poznanych. W związku z postępem wiedzy na temat tej choroby i jej czynnika chorobotwórczego oraz wraz z rozwojem epidemii w Polsce należy na bieżąco dostosowywać i modyfikować system SRWE zgodnie $\mathrm{z}$ aktualną wiedzą.

Ocena kompletności liczby zarejestrowanych wywiadów w porównaniu z oficjalnymi danymi MZ o nowych przypadkach zakażeń SARS-CoV-2 nie pozwala na uznanie modułu COVID-19 za wystarczające narzędzie monitorowania bieżącej sytuacji epidemiologicznej ze względu na zbyt wolne wprowadzanie danych do 
With regard to the assessment of the current epidemiological situation, the COVID-19 module in the SRWE is an important supplement to the ICT system introduced by a unit subordinate to the minister for health competent in the field of health care information systems, i.e. the EWP system and the National Register of Patients with COVID-19. Unlike the EWP system, which is focused on quick collection of basic information, and the clinical registry of COVID-19 patients, the SRWE module is focused on epidemiological investigation and allows the collection of unique information, especially on the spread of infections. Ultimately, the ongoing work aimed at integrating these databases will allow for a more complete register and a full ongoing assessment of the situation related to COVID-19 in Poland. The integration would also reduce the workload of people entering data, i.e. employees of the Sanitary Inspection, doctors, and diagnosticians. This is especially important in the context of the projected second wave of the epidemic in the fallwinter 2020/21 season.

\section{REFERENCES}

1. Huang C, Wang Y, Li X, et al. Clinical features of patients infected with 2019 novel coronavirus in Wuhan, China. Lancet. 2020;395:497-506. doi: 10.1016/S0140-6736(20)30183-5

2. Lu R, Zhao X, Li J, et al. Genomic characterisation and epidemiology of 2019 novel coronavirus: implications for virus origins and receptor binding. Lancet. 2020;395:565-574. doi:10.1016/S01406736(20)30251-8

3. Kraemer MUG, Yang C-H, Gutierrez B, et al. The effect of human mobility and control measures on the COVID-19 epidemic in China. Science. 2020;368:493-497. doi: 10.1126/science.abb4218

4. Lau H, Khosrawipour V, Kocbach P, et al. The positive impact of lockdown in Wuhan on containing the COVID-19 outbreak in China. J Travel Med. 2020;27. doi: 10.1093/jtm/taaa037

5. Chinazzi M, Davis JT, Ajelli M, et al. The effect of travel restrictions on the spread of the 2019 novel coronavirus (COVID-19) outbreak. Science. 2020;368:395-400. doi: 10.1126/science.aba9757

6. WHO Director-General's opening remarks at the media briefing on COVID-19 - 11 March 2020. [cited $2020 \mathrm{Jul}$ 7]; Available from: https://www. who.int/dg/speeches/detail/who-director-generals-opening-remarks-at-the-media-briefing-oncovid-19---11-march-2020

7. Polscy studenci, którzy przylecieli z Wuhan, nie są zarażeni. MedExpress.pl. [cited 2020 Jul 7]; Available from: http://www.medexpress.pl/ systemu, jednak zebrane informacje o zachorowaniach będą istotnym źródłem danych dla analiz podsumowujących przebieg epidemii, w późniejszym czasie.

W odniesieniu do oceny aktualnej sytuacji epidemiologicznej moduł COVID-19 w SRWE jest ważnym uzupełnieniem systemu teleinformatycznego udostępnionego przez jednostkę podległą ministrowi właściwemu do spraw zdrowia właściwą $\mathrm{w}$ zakresie systemów informacyjnych ochrony zdrowia tj. systemu EWP oraz Krajowego Rejestru Pacjentów z COVID-19. W odróżnieniu od systemu EWP ukierunkowanego na szybkie zebranie podstawowych informacji oraz klinicznego rejestru pacjentów z COVID-19, moduł SRWE jest ukierunkowany na dochodzenie epidemiologiczne i pozwala na gromadzenie unikatowych informacji, szczególnie dotyczących szerzenia się zakażeń. Docelowo, prowadzone prace mające na celu integrację tych baz pozwolą na większą kompletność rejestru i pełną bieżącą ocenę sytuacji związanej z COVID-19 w Polsce. Integracja pozwoliłaby również na ograniczenie nakładu pracy osób wprowadzających dane, a więc pracowników Inspekcji Sanitarnej, lekarzy i diagnostów. Jest to szczególnie ważne w kontekście prognozowanej drugiej fali epidemii w sezonie jesienno-zimowym 2020/21.

polscy-studenci-ktorzy-przylecieli-z-wuhan-niesa-zarazeni/76134

8. Polacy $z$ Wuhan już w kraju. Premier: Nikt z nich nie ma objawów choroby. 100AD [cited 2020 Jul 7]; Available from: https://wiadomosci.dziennik. pl/swiat/artykuly/6431004,wuhan-koronawirusewakuacja-polacy-francja.html

9. Pierwszy przypadek koronawirusa w Polsce - Ministerstwo Zdrowia - Portal Gov.pl. Ministerstwo Zdrowia. [cited 2020 Jul 7]; Available from: https://www.gov.pl/web/zdrowie/pierwszyprzypadek-koronawirusa-w-polsce

10. COVID-19 situation update worldwide, as of 30 June 2020 [Internet]. European Centre for Disease Prevention and Control. [cited 2020 Jul 22]; Available from: https://www.ecdc.europa.eu/en/ geographical-distribution-2019-ncov-cases

11. Coronavirus disease 2019 (COVID-19) data Reporting Protocol, Version 3.2, 20 May 2020. Available from: https://www.ecdc.europa.eu/sites/ default/files/documents/covid-19-severe-casereporting-protocol.pdf

12. WHO. Interim case reporting form. Available from: https://www.who.int/docs/default-source/ coronaviruse/20200121-2019-ncov-reportingform.pdf?sfvrsn=96eff954_4

13. E-zdrowie wspiera walkę z pandemią. Centrum e-Zdrowia. [cited 2020 Jul 22]; Available from: https://www.cez.gov.pl/aktualnosci/szczegoly/ezdrowie-wspiera-walke-z-pandemia/ 
14. Case definition for coronavirus disease 2019 (COVID-19), as of 29 May 2020 [Internet]. European Centre for Disease Prevention and Control. [cited 2020 Jul 7]; Available from: https:// www.ecdc.europa.eu/en/covid-19/surveillance/ case-definition

15. Definicja zakażenia SARS-CoV-2 (COVID-19) (stosowana od 16.06.2020 r.). [cited 2020 Jul 22]; Available from: http://wwwold.pzh.gov.pl/oldpage/ epimeld/index_p.html

16. Krajowe Rejestry Medyczne. Krajowy Rejestr Pacjentów z COVID-19. [cited 2020 Jul 22]; Available from: https://rejestrcovid.mz.gov.pl/

17. Mapa zarażeń koronawirusem (SARS-CoV-2) Koronawirus: informacje i zalecenia - Portal Gov. pl. Koronawirus: informacje i zalecenia. [cited 2020 Jul 7];Available from: https://www.gov.pl/web/ koronawirus/wykaz-zarazen-koronawirusemsars-cov-2

18. Novel coronavirus disease 2019 (COVID-19) pandemic: increased transmission in the EU/EEA and the UK - sixth update. 2019;28. Available from: https://www.ecdc.europa.eu/sites/default/ files/documents/RRA-sixth-update-Outbreak-ofnovel-coronavirus-disease-2019-COVID-19.pdf

19. Strategies for the surveillance of COVID-19. Technical Report. :7. Stockholm: ECDC; 2020. https://www.ecdc.europa.eu/en/publications-data/ strategies-surveillance-covid-19

Received: 20.11.2020

Otrzymano: 20.11.2020

Accepted for publication: 2.12.2020

Zaakceptowano do publikacji: $2.12 .2020 \mathrm{r}$.

Address for correspondence:

Adres do korespondencji:

Wioleta Kitowska

Zakład Epidemiologii Chorób Zakaźnych i Nadzoru

Narodowy Instytut Zdrowia Publicznego-PZH

Ul. Chocimska 24, 00-791 Warszawa

Tel. 48225421281

E-mail: wkitowska@pzh.gov.pl 